\title{
The socializing function of the university
}

\author{
Tatiana N. Seregina ${ }^{1 *}$, Sergey A. Prosekov ${ }^{1}$, Sergey $V$. Nazarenko $^{2}$, and Maxim R. Logunov ${ }^{3}$ \\ ${ }^{1}$ Financial University, Department of Humanities, Moscow, Russia \\ ${ }^{2}$ Financial University, Department of Sociology, Moscow, Russia \\ ${ }^{3}$ Higher School of Economics, Faculty of Economic Sciences, Moscow, Russia
}

\begin{abstract}
The article considers the role of the university as a social institution in the urban space. The article establishes the connection and interdependence among the phenomena of the city, the university, the type of rationality, and the type of communication. The transformations of urban space and the functions of the city in history affect the organizational forms and functions of the university. The research environment at the university, using the communication practices that have developed in society, creates a certain type of rationality. The nonclassical type of rationality is formed in the industrial city environment, and university education is changing towards professionalization, and commercialization, changing communication practices and values that need to be mastered for socialization into the industrial world. The post-nonclassical type of rationality coincides with the emergence of a new type of university, created within the framework of the Bologna Process. This is associated with the emergence of so-called multiple identities, formed by a variety of socialization practices. Universities are operating in the global space of global cities and megalopolises. The convergence of these phenomena results in the transformation of the value perception of the world and the axiological paradigm of society. The activity-based method of analyzing the socialization process allowed determining the need to create the idea of a university, based on a value approach. Values and value-based communication practices in the educational system of the university allow moving to a sustainable development society.
\end{abstract}

Keywords: communication, university, city.

\section{Introduction}

The university, as a social institution was historically formed as an institution of socialization. Universities are organized and operate in cities. Their task is to translate urban, civilizational values, and create tools for their assimilation. For a contemporary university, this function remains the main one, while changing only the content of the values that need to be translated, as well as the ways and forms of socialization, the entry of a person into the cultural and social environment.

A contemporary university should correspond to the type of contemporary society, which is generally characterized as a consumerist, post-industrial, global, mass, information, being

\footnotetext{
${ }^{*}$ Corresponding author: seregina.tatiana@gmail.com
} 
a society of knowledge and service. Even the enumeration of the names of contemporary society characterizes its diversity and the multiplicity of value categories that this society reflects. The university, being the basic socialization institution, must necessarily reflect these values and develop methods and mechanisms for translating values.

\section{Methods}

The authors used a critical analysis method that allowed revealing the dialectical essence of the university development as a social institution, performing the function of socialization to urban and civilizational values.

\section{Results}

The city is a unique phenomenon for the functioning of the socialization and enculturation processes, which can be considered its main functions. The socialization process is generally understood as the permanent transfer and assimilation of norms, values, rules, and types of social practices necessary for functioning in society. Socialization is effective if the individual has mastered the stereotypes of behavior, values, worldview, as well as if he has undergone the adaptation process, and identifies himself with one or more groups [1].

In order to understand the essence of the socialization function, it is necessary to find out the place and role of the university in the contemporary world. Science distinguishes three types of rationality, namely, classical, nonclassical, and post-nonclassical. One can speak about the corresponding types of communication, based on the types of rationality. Communication was the basis for the socialization processes which have received their institutional development through the creation of the first schools, and later - universities and academies.

The three types of communication and the three types of rationality correspond to the three types of university models. Thus, universities can be represented through three models - classical, nonclassical, and post-nonclassical.

The classical university performs the function of transmitting knowledge and reproducing it based on fundamental science, this is elite knowledge, while the purpose of training is to educate the spirit, and striving for the spiritual ideal.

The nonclassical model is focused on branch knowledge. It emerged in the period of forming disciplinarily organized science which was characterized by a transition from the model based on the "cult of the teacher" to the individualization and subject-to-subject relations. The desire for individual actualization rather than spiritual improvement has become the main goal of the educational process. A nonclassical university is created as a professional one, and its task is to teach knowledge that would bring income and profit through commercialization of the very university. At that, the university retains its humanistic function. A positive aspect of the nonclassical model of the university is the orientation towards an independent person who chooses education as a way of selfimprovement. The dialogue between the teacher and the student creates a space for the production of values, norms, meanings, rather than just for their transmission. By the 20th century, the quantity of knowledge and its quality do not allow the university to be only a producer of new knowledge. Education is becoming widespread, and the industrial urban world requires a large number of educated people and specialists.

The post-nonclassical model of the university provides interdisciplinary knowledge aimed at solving a specific theoretical or practical problem along with emerging projectbased learning. The purpose of training is to form competencies for gaining an identity and effective socialization. Education is not limited just to studying at the university. The post- 
nonclassical model of the university retains the focus of education on commercialization, but the basis of the educational process is an interdisciplinary approach, the need for tolerance in education and communication. While earlier the university was an institution that transmitted values and guides that allowed socialization, the post-nonclassical university makes it possible to build its peculiar identity models, i.e. "situational identity". Project-based learning is transformed into innovative learning.

The project of transferring university education to the Bologna Process has become possible under the influence of global trends and important due to the following factors: formation of a knowledge society, information and post-information society, which are determined by the quality of education; development of the technologies and communications; emergence of multicultural social medium and multiple identities; migration and mobility, which on the one hand, have created the need for the universalization of social practices and value paradigms, and on the other hand, have increased competition within the local worlds. All these factors are accumulated in urban spaces and cannot exist without them. As a result, universities have found themselves in a situation where education became mass, knowledge was standard, and research results were available, while the economy required innovation, uniqueness, and elitism. The Bologna Process, describing the processes associated with socialization, reduces most of the cultural processes carried out by the university to mobility as a marker of the success of the university. K.P. Liessmann proved in his work [2] that the global processes taking place in education, and changes in curricula have made university education uniform, standard and unified, which makes the criterion of mobility unnecessary.

The function of socialization through the university as an institution corresponds to the content of the Bologna declaration: preparing for entering the economic market, developing an active life stance, uncovering personal potential, forming self-improvement skills, being able for critical self-reflection and dialogue based on trust and responsibility. Within the framework of the educational process, the formed personality qualities are conceptually reinforced as competencies [3: 138]. Thus, the competency-based approach is formed within the framework of the activity-based approach to the socialization processes, traditional for Russian and Soviet pedagogy.

\section{Discussion}

Russian researchers focus on the dynamic development of social reality, methodologically basing their conclusions on the use of the activity-based approach in the study of socialization processes. The competency-based approach to education, upbringing, and socialization, in general, is also associated with the activity-based approach [4]. The main goal of such socialization was the growth of professional qualities since the universities that won in the rankings were research universities that carried out research projects [5].

Concerning the issues of socialization of university education, foreign authors still question selecting and translating value structures, while it is them that form the framework of the competency-based education system. At that, the basic and functional value systems used in education are developed by Western authors. These concerns works of J. Rawls [6], psychological theories of socialization, developed by J. Piaget, L. Kohlberg [7], and M. Rokeach [8], as well as S. Pinker's theories [9].

The issues of the identification process are considered in the works of C. Kerr, J.H. Newman [10], J. Ortega y Gasset [11], H.M. McLuhan, M. Castells, and A. Flexner. The works of Z. Bauman, D. Bell, G. Ritzer, C. Kerr, A. Toffler, and K. Jaspers, reveal the ideas of the mutual influence of the university, the city, and society [12-14]. 


\section{Conclusion}

The article establishes correlations between the type of city, the dominant type of rationality, communication practices, and the values that are transmitted by the university as a social institution. The concept of Sustainable Urban Development adopted by the UN is based on the most important values of the contemporary world, namely, ecology, solidarity, overcoming inequality, access to education, and building human capital. The problem of communication, security, and the role of institutions in the processes of socialization and the incorporation of values has become the subject of interdisciplinary research [15].

In Russian science, the problems of tragic gaps between man and technology, institutions and values, information and its interpretation are in the focus of attention [16]. The next step in implementing the sustainable development program will be a discussion about the opportunities and resources of universities as institutions of socialization. It is necessary to realize the humanizing function of the university in the transformation of society and to form mechanisms that would ensure the transmission of the values of solidarity, mutual understanding, trust, and tolerance.

\section{References}

1. E.G. Bagreeva, Sotsiokul'turnyye problemy v kriminologii [Sociocultural problems in criminology] (All-Russian Research Institute of the Ministry of Internal Affairs of the Russian Federation, Moscow, 2001)

2. K.P. Liessmann, The theory of miseducation (Vienna, Hanser Verlage, 2006)

3. N.G. Muravieva, Tyumen State University Herald. Social, Economic, and Law Research, 9, 136-143 (2011)

4. A.-K. Koenen, F. Dochy, I. Berghmans, Teaching and Teacher Education, 50, 1-12 (2015). http://dx.doi.org/10.1016/j.tate.2015.04.001

5. R. Land, G. Gordon, Enhancing quality in higher education - international perspectives (Routledge, London, New York, 2013)

6. J. Rawls, A Theory of justice (The Belknap Press of Harvard University Press, Cambridge, Massachusetts, 1999)

7. R. Blair, The development of morality. Thesis (University of London, London, 1992). Accessed on: December 02, 2020. [Online]. Available: https://discovery.ucl.ac.uk/id/eprint/1318028/1/318556.pdf

8. M. Rokeach, Understanding human values: individual and societal (The Free Press, New York, 1979)

9. S. Pinker, The blank slate: the modern denial of human nature (Penguin Books, New York, 2002)

10. J.H. Newman, The idea of a university (Aeterna Press, London, 2015)

11. H. Ortega-y-Gasset, Journal of American History, 32(2), 266-267 (1945). https://doi.org/10.2307/1898222

12. H. Spencer-Oatey, Journal of Studies in International Education, 17(3), 244-261 (2013). https://doi.org/10.1177\%2F1028315312454545

13. I. Anuzienė, Vocational Training: Research and Realities, 26(1), 1-12 (2015). https://doi.org/10.1515/vtrr-2015-0006

14. R.J. Shavelson, An approach to testing and modeling competence, in Modeling and measuring competencies in higher education tasks and challenges, 29-43 (Sense Publishers, Rotterdam, 2013) 
15. R. Inglehart, C. Haerpfer, A. Moreno, C. Welzel, K. Kizilova, J. Diez-Medrano, M. Lagos, P. Norris, E. Ponarin, B. Puranen et al. (Eds.). World values survey: All roundscountry-pooled datafile version (JD Systems Institute, Madrid, 2014). Accessed on: December 01, 2020. [Online]. Available:

https://www.worldvaluessurvey.org/WVSDocumentationWVL.jsp

16. A.D. Ioseliani, N.V. Tskhadadze, The era of chance - a new stage of alienation, in Marx and modernity. A political and economic analysis of social systems management, 239-248 (Information Age Publishing Inc., Charlotte, NC, 2019) 